\title{
Evaluation of Urban Waterfront Redevelopment Process in Banjarmasin City, South Kalimantan Province, Indonesia
}

\author{
Andini Amalia Rifky ${ }^{\mathrm{a}}$, Bambang Supriyono ${ }^{\mathrm{b}}$, Alfi Haris Wanto ${ }^{\mathrm{b}}$, Motoko Kawano ${ }^{\mathrm{c}}$ \\ ${ }^{a}$ Public Work of Banjarmasin City, South Kalimantan Province, Indonesia \\ ${ }^{b}$ Brawijaya University, Malang, East Java, Indonesia \\ ${ }^{c}$ National Graduate Institute for Policy Studies, Tokyo, Japan
}

\section{ARTIC LE INFORMATION}

\section{Article history:}

Date submission: 14 Agustus 2017

First revision: 07 Juni 2017

Accepted: 14 Juni 2017

Online available: 28 November 2017

Keywords: urban waterfront redevelopment, river normalization, creating new economy, redescovering identity, decentralization

\section{ABSTRACT}

Waterfront project toward urban redevelopment has become common in many countries, including Indonesia. Based on the field survey and documents research in Banjarmasin, during 2016 to 2017, this study aims to evaluate the urban waterfront redevelopment. This study revealed that there are three phases of Banjarmasin waterfront redevelopment process, namely river normalization, creating a new economy, and rediscovering identity. Findings suggested that Banjarmasin government has attained success in both the physical development and the maintenance of the traditional river culture as Banjarmasin's image. Another finding also suggested that decentralization has a part to play in the Banjarmasin waterfront process, because Banjarmasin government gives more attention on waterfront projects, by allocating a huge budget for this purpose.

\section{INTISARI}

Pembangunan tepian sungai di daerah perkotaan telah menjadi hal yang biasa di banyak negara, termasuk Indonesia. Berdasarkan pada hasil survey lapangan dan telaah dokumen di Banjarmasin, selama 2016 hingga 2017, makalah ini bertujuan untuk mengevaluasi pembangunan kembali tepian sungai perkotaan. Makalah ini mengungkapkan bahwa proses pembangunan tepian sungai di Banjarmasin terdiri dari tiga tahap, yaitu normalisasi sungai, menciptakan ekonomi baru, dan menemukan kembali identitas kota. Temuan dari makalah ini menunjukan bahwa Pemerintah Banjarmasin telah berhasil dalam pembangunan fisik maupun pemeliharaan budaya sungai tradisional sebagai citra Banjarmasin. Temuan lainnya menunjukkan bahwa desentralisasi memiliki peran dalam proses pembangunan tepian sungai di Banjarmasin, karena Pemerintah Banjarmasin memberikan perhatian lebih dalam proyek ini, dengan mengalokasikan anggaran yang besar untuk tujuan ini.

2017 FIA UB. All rights reserved.

\section{Introduction}

Urban waterfront redevelopment has become common in many countries (see, Breen \& Rigby, 1994, 1996; Dong, 2004; Stevens, 2009). In Indonesia, urban waterfront redevelopment has already been implemented in Manado involving various stakeholders in tourism and other sectors (Lagarense \& Walansendow, 2015). It was quite similar in Makassar, which is an urban waterfront located in a coastal area with public space and tourist attractions while retaining its local identity (Erham \& Hamzah, 2014). The Singapore River waterfront is an open space and a tourist attraction, but it lacks a local identity (Chang, Huang, \& Savage, 2004).

* Corresponding author. Tel.: +62-821-5794-4197; e-mail: andini.coklat@gmail.com 
Banjarmasin, located in South Kalimantan Island, has uniquely characteristic of rivers and creeks. Banjarese call it "the city of a thousand rivers" which is a reflection of the 102 rivers that flow across in this city. Until now, the river has been used by the people for daily activities such as trade, a shower and even an alternative urban transport. There are two major rivers, the Barito and Martapura River. Martapura River runs for $11.70 \mathrm{~km}$ from Banjar Regency in the upstream to Banjarmasin, as an estuary (Statistics of Banjarmasin, 2015). It is a river that divides the city of Banjarmasin and is influenced by the tides of Java Therefore, it contributes to the city's drainage and provide distinctive characteristics to the people's lives, especially regarding the use of the river as a water transport infrastructure, for tourism, fisheries, and trade. Unfortunately, (Subiyakto, 2004) stated that the orientation of development in Banjarmasin tended to the land sector and neglected the water functions, such as for transportation use.

But currently, the Banjarmasin government also facing water problems, which are mentioned in the Spatial Planning and Medium Development Planning of Banjarmasin City, such as river side slum area, flood, and environmental problem that is affecting the housing settlements along the rivers. Because of this, Banjarmasin City has started to normalize the use of rivers, as a strategic plan to achieve Banjarmasin's image as the "City of thousand rivers that safe, convenient, interesting, to strengthen social, culture, tourism, trade and services activities".

Furthermore, urban waterfront redevelopment has already been implemented in Banjarmasin City since 2004. In the following years, Banjarmasin government divided this project into nine sections.

This is serves its goals to create a public space, tourism attraction, economic improvement, and also local identity. After decentralization was implemented in Indonesia, the Banjarmasin government gave more attentions to the waterfront project, by allocating it the fourth largest budget, after road, education, and the health sector (see Figure 1).

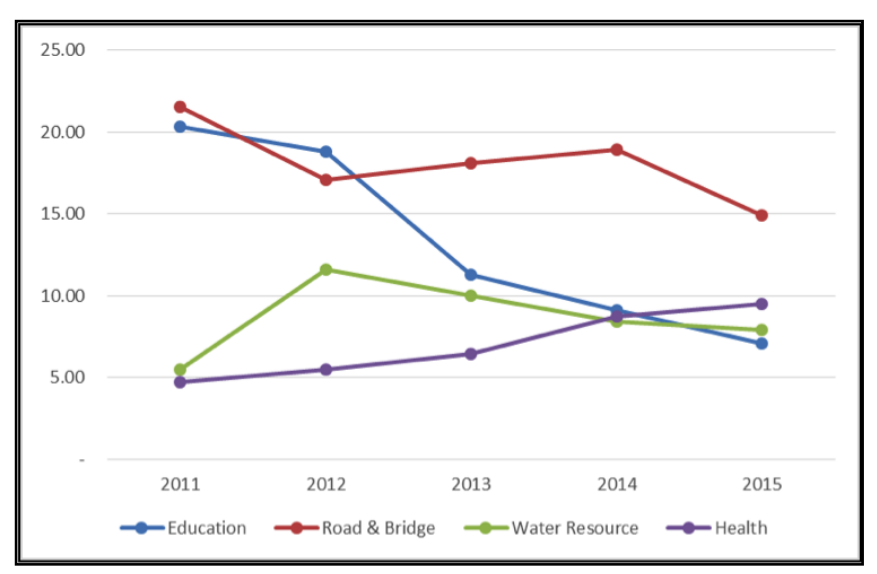

Figure 1. Local Budget of Main Sectors

Source: Financial Bureau documents, 2011-2015

However, there are a limited number of studies on urban waterfront redevelopment in the riverside area that promotes river culture as a city identity. For example, in Singapore, only the physical development of the waterfront is evaluated. The same case applies in Makassar, where only evolution of the waterfront is discussed. In order to fill this gap, this paper aims to evaluate the urban waterfront redevelopment process in Banjarmasin. Furthermore, this study also seeks to discuss the actions of the local government resolving the problems mentioned before, and the Banjarmasin government's introduction of urban waterfront redevelopment as a response to the housing settlement along the rivers.

This study, firstly, evaluates the urban waterfront redevelopment process in Banjarmasin. Secondly, its goal is to describe how the Banjarmasin government rediscovers its local identity. And finally, this study will consider the relevant implications for the whole project of the Banjarmasin waterfront.

\section{Theory}

\subsection{Urban Redevelopment}

In the literature, there are many terms that are used synonymously with urban redevelopment, such as "urban renewal" (see in Couch, Sykes, \& Borstinghaus, 2011; Verhage, 2005), "urban regeneration" (see in Cadell, Falk \& King, 2008; Robert, 2000), and "urban redevelopment" (see in Gotham, 2001; Garvin, 2002).

In European cities urban renewal or urban regeneration are more common rather than urban redevelopment. Urban redevelopment refers to the slum removal process in urban areas (Couch, Sykes, \& Borstinghaus, 2011). Urban renewal refers to the combination of processes that include social, economic and physical improvement of an area. Mostly, urban renewal is initiated by the public sector in collaboration with other stakeholders. There are five aspects of urban renewal, which are: housing, public space, amenities, social, and fiscal aspects (Verhage, 2005).

Urban regeneration refers to the long-term process that includes many stakeholders. At Norra Alvstranden in Sweden; Kop van Zuid in the Netherlands, and Roubaix in France, the local authority had an important role in the urban regeneration process, not only for improvement but also for assisting in the transformation of the city's image, to have more economic bargaining positions (Cadell, Falk, \& King, 2008). Urban regeneration is a comprehensive and continuous action for resolving urban problems, which include the economic, physical, social, and environmental improvement conditions of the area (Roberts, 2000).

Roberts (2000) explained the evolution of the urban regeneration process (see Table 1). It started after World War II, in the 1950s, when the term "reconstruction" was used. In reconstruction, the main strategy was restoration by rebuilding or reconstructing an old area or an existing area. The central and local government, together with the private sector, became the key leading actors in the process of urban reconstruction. The terms "rehabilitation" or "revitalization" appeared in the 
1960s, when the public and private sectors were still the key actors in the process of revitalization.

In the 1970s, the term "renewal" or "reform" was used. The scope of the renewal area was broader than before, and the physical development was more comprehensive and continuous. There is also an increasing role of private sectors and the local government, because of the decentralization, seen during this period. Until the 1980s, the term "redevelopment" was used, which has a wide scale of meaning regarding the basic physical development of each function in the region. Finally, in the 1990s, the terms evolved from "redevelopment" to "regeneration" process that considers all the social, economic, and environmental aspects comprehensively through physical development with broader a concept.

Table 1. The Evolution of Urban Redevelopment

\begin{tabular}{|c|c|c|c|c|}
\hline Period & $1950 \mathrm{~s}-1960 \mathrm{~s}$ & $1970 s$ & $1980 s$ & $\begin{array}{l}\text { 1990s- } \\
\text { present }\end{array}$ \\
\hline $\begin{array}{l}\text { Policy } \\
\text { type }\end{array}$ & $\begin{array}{l}\text { Reconstructio } \\
n \& \\
\text { revitalization }\end{array}$ & Renewal & $\begin{array}{l}\text { Redevelopme } \\
\text { nt }\end{array}$ & $\begin{array}{l}\text { Regenerati } \\
\text { on }\end{array}$ \\
\hline $\begin{array}{l}\text { Major } \\
\text { strategy } \\
\text { and } \\
\text { orientati } \\
\text { on }\end{array}$ & $\begin{array}{l}\text { Reconstructio } \\
n \text { of old areas }\end{array}$ & $\begin{array}{l}\text { Focus on } \\
\text { renewal with } \\
\text { a } \\
\text { neighborhood } \\
\text { concept }\end{array}$ & $\begin{array}{l}\text { Introduction } \\
\text { of the } \\
\text { redevelopmen } \\
\text { t concept }\end{array}$ & $\begin{array}{l}\text { Move } \\
\text { towards an } \\
\text { integrated } \\
\text { policy }\end{array}$ \\
\hline $\begin{array}{l}\text { Econom } \\
y\end{array}$ & $\begin{array}{l}\text { Financing } \\
\text { from public } \\
\text { sector, with } \\
\text { some } \\
\text { investments } \\
\text { from the } \\
\text { private sector }\end{array}$ & $\begin{array}{l}\text { Growth role } \\
\text { of private } \\
\text { sector, with } \\
\text { the public } \\
\text { sector still } \\
\text { dominating } \\
\text { the financial } \\
\text { aspect }\end{array}$ & $\begin{array}{l}\text { Domination } \\
\text { of the private } \\
\text { sector }\end{array}$ & $\begin{array}{l}\text { Balanced } \\
\text { role } \\
\text { between the } \\
\text { public and } \\
\text { private } \\
\text { sector }\end{array}$ \\
\hline Social & $\begin{array}{l}\text { Focus on } \\
\text { improvement } \\
\text { of settlement } \\
\text { and welfare }\end{array}$ & $\begin{array}{l}\text { Community } \\
\text { participation }\end{array}$ & $\begin{array}{l}\text { Community } \\
\text { participation }\end{array}$ & $\begin{array}{l}\text { Initiation } \\
\text { from local } \\
\text { people }\end{array}$ \\
\hline Physical & $\begin{array}{l}\text { Replace some } \\
\text { old areas }\end{array}$ & $\begin{array}{l}\text { Comprehensi } \\
\text { ve to renewal } \\
\text { of old areas }\end{array}$ & $\begin{array}{l}\text { Replacement } \\
\text { concept }\end{array}$ & $\begin{array}{l}\text { Include } \\
\text { heritage } \\
\text { restoration }\end{array}$ \\
\hline $\begin{array}{l}\text { Environ } \\
\text { mental } \\
\text { approac } \\
h\end{array}$ & $\begin{array}{l}\text { Introducing } \\
\text { the green } \\
\text { concept }\end{array}$ & $\begin{array}{l}\text { Some } \\
\text { innovation on } \\
\text { the } \\
\text { environmenta } \\
l\end{array}$ & $\begin{array}{l}\text { Broader } \\
\text { environmenta } \\
\text { l concept }\end{array}$ & $\begin{array}{l}\text { Introducing } \\
\text { sustainable } \\
\text { environmen } \\
\text { tal concept }\end{array}$ \\
\hline
\end{tabular}

Source: Modified by the author from Roberts (2000).

\subsection{Urban Waterfront Redevelopment}

In the literature, there are many definitions available for describing the waterfront. According to Oxford Learner's Pocket Dictionary 2011, waterfront is "the part of a town or area that is next to water". Dong (2004) stated that waterfront is land located in front of water. Generally, waterfront can be defined as an area that has an interaction between land and water (see in Hou, 2009; Wrenn, Casazza, \& Smart, 1983; Yassin, Eves \& McDonagh, 2010).

Breen \& Rigby (1994) argued that the urban waterfront has two definitions. First, waterfront is described as the edge of the water in the cities, including all sizes of water bodies, like coastal, bay, lake, river, creek, and even canal. The second definition is that waterfront development may not be directly linked to the water, but have a visual or historical link to it. For instance, Brooklyn Esplanade in New York and Pike's Place Market in Seattle have become a part of the waterfront even though they are not directly on the water. It also stated that urban waterfront development started with the decline of port functions and deindustrialization, with an abandoned land being changed into an open space area.

Waterfront development refers to the development that is directly in front of the water features such as coastal areas, beaches, lagoons, riverbank, and other such water features (Yassin, Bond, \& McDonagh, 2011). Goodwin (1999) assumed that a waterfront is intended for recreation and as a public space for people. In his paper, he used the term "waterfront revitalization" that referred to a series of planning stages and public hearings that involve a community.

According to the definitions above, a waterfront that located in between the land and water has special characteristics, such as "dynamic area, habitat, natural defense and as pollution moderator" (Yassin, Eves, \& McDonagh, 2010).

\section{Research Method}

This research was conducted during 2016 to 2017. It used a qualitative method with descriptive analysis. The data consisted of primary as well as secondary data. The primary data were collected through interviews and questionnaires. The interviews were conducted to get more information about the waterfront project in Banjarmasin from the key informants in either the government or the associations. The interview questions were about the waterfront redevelopment progress and the role of the stakeholders.

Moreover, the questionnaires were also given to the members of the floating market association and boat association. The questionnaire was composed of three parts. The first part asked questions about the basic information related to the socio-demographic condition of the respondents. The second part asked questions about the livelihood and income of the respondents. And, the last part asked questions about the association membership, particularly how they got recruited and their activities within the associations.

Meanwhile, the secondary data consisted of a report on waterfront projects, spatial plan, Banjarmasin in figures, departments' reports, maps, newspapers, and literature.

\section{Result and Discussion}

\subsection{Process of waterfront development project from 2009 to the present}

According to the Department of Water Resource and Drainage (2008), Banjarmasin waterfront projects consist of nine sectors situated along Martapura River. The author divided it into two areas, the northern area and southern area (see Figure 2). The northern area consist of section 1 to 5 (respectively The Grand Mosque Waterfront, Piere Tendean Park, Old Market Waterfront, Bekantan Park, Post Street Food Court), and 
the southern area consist of section 6 to 9 (respectively Sungai Baru Waterfront, R.K. Ilir Waterfront, Ujung Murung Waterfront, City Hall Waterfront). The Banjarmasin waterfront redevelopment was started the Grand Mosque waterfront (Section No. 1) in 2004.

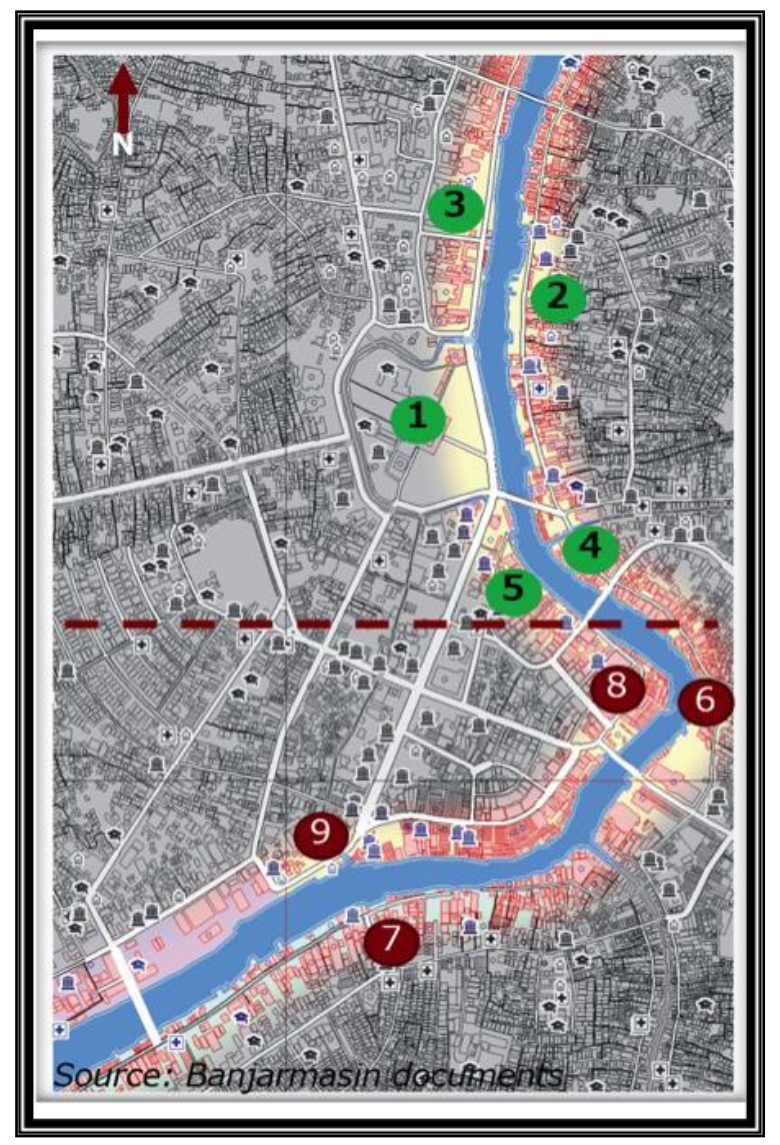

Figure 2. Banjarmasin Waterfront Projects

Source: Constructed by the author from Department of Water Resources and Drainage of Banjarmasin Municipality, 2008.

Furthermore, the budget for the Banjarmasin waterfront came from the central, provincial, and local governments (see Table 2).

Table 2. Budget source of Banjarmasin Waterfront until present day

\begin{tabular}{|c|c|}
\hline Budget source & Total (on billion IDR) \\
\hline Central government & $\underline{62.5}$ \\
\hline Provincial government & 18.3 \\
\hline Local government & 126.8 \\
\hline
\end{tabular}

After finishing the Grand Mosque waterfront, the remaining projects were constructed. In 2008, the Ujung Murung waterfront project began with a multi-year program, until it was finished in 2012. It was fully funded by the local government's budget and cost about 19 billion IDR (approximately 1.4 million USD).

The next year, in 2009, Banjarmasin City built another sector, called the Piere Tendean Park (Section No. 2). For this project, there was a collaboration between the central and local government and they were sharing responsibility for both the construction and funding. This project took almost six years to be completed, until it was finished in 2014 with total a length about $958 \mathrm{~m}$ and an expenditure of about 48 billion IDR (approximately 3.6 million USD).

There are three phases of the Banjarmasin waterfront redevelopment process, the river normalization process, creating a new economy, and rediscovering the local identity.

Furthermore, the study only focuses on the northern part of the area, which includes section 1 to 5 . Those are located in the Central Banjarmasin Sub-district. The waterfront has a strategic location, surrounded by central business sub-districts, such as Sasirangan village and Old Market Square to the North, the Grand Mosque and Government offices to the West, Mixed-used and offices areas, both in the public and private sectors towards the East, and Ketupat village to the South. The location also complies with the Building Management and Environmental Plan (Rencana Tata Bangunan dan Lingkungan/RTBL) to be developed as a public green space area.

\subsection{First Phase: River Normalization}

The river normalization process was divided into two steps, namely the cleaning up process and then building the river walk.

\section{Cleaning up process}

The cleaning up process aimed to clean up the riverside from housing settlements. This process took almost six years, from 2008 and 2016 to clean up 3 sections (Piere Tendean Park, Bekantan Park, and Old Market).

The process of river normalization in section 2 (referring to the Piere Tendean waterfront) was quite difficult. It took several months for the local government to reach an agreement with all the households in that area. Section 2 is located between the Old Market Bridge and Independence Bridge, and covers two kelurahans, namely Gadang and Seberang Masjid kelurahan. The whole area was residential, with and without the relevant documents (see Table 3).

Table 3. Cleaning up process

\begin{tabular}{|c|c|c|c|}
\hline Sectors & $\begin{array}{c}\text { Cleaning up } \\
\text { river side } \\
\text { area }\end{array}$ & $\begin{array}{l}\text { Budget for } \\
\text { cleaning up }\end{array}$ & Location \\
\hline $\begin{array}{l}\text { Piere } \\
\text { Tendean } \\
\text { Park }\end{array}$ & $\begin{array}{l}-2008-2009, \\
2013 \\
-49 \\
\text { households } \\
\text {, consisting } \\
\text { of } 36 \\
\text { documente } \\
\text { d houses, } \\
13 \\
\text { undocumen } \\
\text { ted houses. }\end{array}$ & $\begin{array}{l}\text { - Average price } \\
\text { of compensation } \\
\text { during 2008- } \\
\text { 2013: } \\
\text { a. Documente } \\
\text { d houses: } \\
146 \text { million } \\
\text { IDR/house, } \\
\text { b. Undocumen } \\
\text { ted houses: } \\
\text { 0.75 million } \\
\text { IDR/house }\end{array}$ & $\begin{array}{l}\text { - Kelurahan } \\
\text { Gadang } \\
\text { (RT 37, 38, } \\
\text { 39, and 40) } \\
\text { - Kelurahan } \\
\text { Seberang } \\
\text { Masjid } \\
\text { (RT. 07, } \\
\text { 15, 16, and } \\
\text { 29) }\end{array}$ \\
\hline $\begin{array}{l}\text { Bekanta } \\
\text { n Park }\end{array}$ & $\begin{array}{l}-2011-2012 \\
-57 \\
\quad \text { households } \\
\end{array}$ & & $\begin{array}{l}\text { Kelurahan } \\
\text { Gadang }\end{array}$ \\
\hline
\end{tabular}




\begin{tabular}{|c|c|c|}
\hline & $\begin{array}{l}\text {, consisting } \\
\text { of } 42 \\
\text { documente } \\
\text { d houses, } \\
15 \\
\text { undocume } \\
\text { nted } \\
\text { houses. }\end{array}$ & \\
\hline $\begin{array}{l}\text { Old } \\
\text { market }\end{array}$ & $\begin{array}{l}-2011 \\
-37 \\
\text { households } \\
\text {, consist of } \\
25 \\
\text { documente } \\
\text { d } \\
\text { households } \\
, 12 \\
\text { undocumen } \\
\text { ted } \\
\text { households }\end{array}$ & $\begin{array}{l}\text { Kelurahan } \\
\text { Antasan } \\
\text { Besar }\end{array}$ \\
\hline
\end{tabular}

Source: Author's compilation based on Banjarmasin City government's document (various years)

The local government started the cleaning process in 2008 at Gadang kelurahan in Central Banjarmasin subdistrict. According to Mayor Decree No. 103 Year 2008 regarding the Amount of Building Compensation in Piere Tendean Street, there were 9 households, covering a total area of $1,834 \mathrm{~m}^{2}$. The amount of compensation was divided into the following two kinds of certified titles: rights to build ("Sertifikat Hak Guna Bangunan" or "SHGB") will get a compensation of 500,000 IDR per $\mathrm{m}^{2}$ (approximately 37 USD per $\mathrm{m}^{2}$ ), and freehold ("Sertifikat Hak Milik" or "SHM") will get a compensation of 750,000 IDR per $\mathrm{m}^{2}$ (approximately 56 USD per $\mathrm{m}^{2}$ ). The local government allocated 1.3 billion IDR (approximately 98,464 USD) for the compensations in Gadang kelurahan.

After finishing the cleaning process in Gadang kelurahan, the local government continued their work there in 2009. According to the appraisal team, 26 households in Seberang Masjid kelurahan agreed to have their houses demolished for the waterfront development for a compensation of around 900,000 IDR per $\mathrm{m}^{2}$ or approximately 68 USD per $\mathrm{m}^{2}$ (Rahmadhani, Banjarmasin Post, 2009).

Hereafter, the appraisal team also listed 13 undocumented houses next to the Old Market Bridge, located in Seberang Masjid kelurahan. According to them, the local government only allowed compensation or cleaning fee of around 750,000 IDR per household (approximately 56.3 USD per household), or a total amount of around 9.75 million IDR (approximately 728.5 USD). It was quite lower than the price given to 26 other households who got the compensation. The local government had their own reasons for lowering the price, declaring that households were located on state land (NN, Banjarmasin Post, 2010).

The disagreement between the local government and the 13 households was quite intense. Finally, the second warning letter sent by the local government ended the disagreement between them. The warning letter informed the households that they needed to demolish their houses before the deadline on $1^{\text {st }}$ November 2010.
If they refused, the local government would do it. And later, in $31^{\text {st }}$ October 2010, the families decided to move their houses by themselves and agreed to take the compensation price (NN, Banjarmasin Post, 2010).

The construction part started in 2009 , funded by the central government with around 2.4 billion IDR (approximately 1.8 billion USD) to build a $90 \mathrm{~m}$ riverwalk (Department of Water Resource and Drainage, 2014). At the same time, Banjarmasin City also got another financial support from the central government through the Strengthening Fiscal Decentralization and Acceleration of Regional Development Fund Fiscal Year 2009 (Dana Penguatan Desentralisasi Fiskal dan Percepatan Pembangunan Daerah TA 2009). With a budget of around 9.7 billion IDR (approximately 729,000 USD), Banjarmasin City built a $280 \mathrm{~m}$ of long riverwalk (Department of Water Resource and Drainage, 2014). The construction work continued until it was finished in 2014.

The river normalization process in section 2 (referring to the Bekantan Park) was quite similar to section 1, in term of the cleaning up problem. Section 2, located from Independence Bridge to Dewi Bridge, is an extension of the Piere Tendean Park. The area was a residential one, with and without the relevant documents. To continue the waterfront development, the local government needed to clean up the area, but the process was not easy. The process of river normalization took several months.

At first, Banjarmasin City through the Governance Bureau (Bagian Tata Pemerintahan/TAPEM), created the appraisal team to determine the property price. According to the appraisal team, around 57 houses were found, both with and without the documents (Maskuriah, ANTARA Kalsel.com, 2012).

The process was delayed for several months because the appraisal team needed a consultation about the property price with the central appraisal team (Hanafi, Banjarmasin Post, 2012). At the time, the appraisal team decided to give 1.2 million IDR per $\mathrm{m}^{2}$ (approximately 90 USD per $\mathrm{m}^{2}$ ) compensation for households with documented housing, and only IDR $1,500 / \mathrm{m}^{2}$ (approximately 0.1 USD per $\mathrm{m}^{2}$ ) for households who had a house without the documents (Maskuriah, ANTARA Kalsel.com, 2012).

The payment process took place on two different dates, in August $31^{\text {st }}$ and September $3^{\text {rd }}$ of the year 2012. For the first set of payments, the local government gave the compensation to 18 of the documented housings and 11 of the undocumented housings. For the last payment, the local government gave the compensation for 24 documented housings and 4 undocumented housings, with a total budget of around IDR 4.3 billion (approximately 323,000 USD). After all the households got their compensation, they were given around a week to remove their houses by themselves (Restudia, Banjarmasin Post, 2012).

\section{Building the river walk}

As mention before, since 2004, the provincial government had been building the Grand Mosque waterfront from its budget. At the time, the central government that took responsibility for the construction part chose to start the project on the abandoned school site to avoid delays (Hanafi, Banjarmasin Post, 2012). The construction took many years to be completed, until 
2012 to 2013 (see Table 4). The length of the waterfront was around $114 \mathrm{~m}$, when it was finished in 2012, with a central budget of around 9 billion IDR (approximately 676,000 USD). Continuing till 2013, the contractor finished the $90 \mathrm{~m}$ of long riverwalk with a budget of around 8 billion IDR (approximately 601,000 USD) (Department of Water Resource and Drainage, 2014).

Table 4. Building river walk process

\begin{tabular}{|c|c|c|c|}
\hline Sectors & $\begin{array}{l}\text { Building } \\
\text { river } \\
\text { walk }\end{array}$ & $\begin{array}{l}\text { Budget for } \\
\text { building river } \\
\text { walk }\end{array}$ & Key roles \\
\hline $\begin{array}{l}\text { Piere } \\
\text { Tendean } \\
\text { Park }\end{array}$ & $\begin{array}{l}\text { 2009- } \\
\text { 2014: } 958 \\
\mathrm{~m}\end{array}$ & $\begin{array}{l}\text { - State budget: } \\
33.8 \text { billion } \\
\text { IDR ( } 669 \mathrm{~m}) \\
\text { - Provincial } \\
\text { budget: } 2.7 \\
\text { billion IDR } \\
\text { (green park } \\
8,400 \mathrm{~m}^{2} \text { ) } \\
\text { - Local budget: } \\
15.3 \text { billion } \\
\text { IDR ( } 289 \mathrm{~m}) \\
\text { and viewing } \\
\text { tower: } 16 \\
\text { billion IDR }\end{array}$ & $\begin{array}{l}\text { - The central } \\
\text { government } \\
\text { - The } \\
\text { provincial } \\
\text { government } \\
\text { - The local } \\
\text { government }\end{array}$ \\
\hline $\begin{array}{l}\text { Bekantan } \\
\text { Park }\end{array}$ & $\begin{array}{l}\text { 2012- } \\
\text { 2016: } 204 \\
\mathrm{~m}\end{array}$ & $\begin{array}{l}\text { - State budget: } \\
17 \text { billion } \\
\text { IDR } \\
\text { - Local budget } \\
\text { for Bekantan } \\
\text { statue: } 2.6 \\
\text { billion IDR }\end{array}$ & $\begin{array}{l}\text { - } \begin{array}{l}\text { The central } \\
\text { government }\end{array} \\
\text { - } \begin{array}{l}\text { The local } \\
\text { government }\end{array}\end{array}$ \\
\hline $\begin{array}{l}\text { Grand } \\
\text { Mosque }\end{array}$ & $\begin{array}{l}\text { 2004- } \\
\text { 2006: } 320 \\
\mathrm{~m}\end{array}$ & $\begin{array}{l}\text { Provincial } \\
\text { budget: } 15.7 \\
\text { billion IDR } \\
\end{array}$ & $\begin{array}{l}\text { The provincial } \\
\text { government }\end{array}$ \\
\hline Old market & $\begin{array}{l}\text { 2011- } \\
\text { 2015: } 401 \\
\mathrm{~m} \\
\end{array}$ & $\begin{array}{l}\text { Local budget: } \\
28.7 \text { billion } \\
\text { IDR }\end{array}$ & $\begin{array}{l}\text { The local } \\
\text { government }\end{array}$ \\
\hline $\begin{array}{l}\text { Post Street } \\
\text { Food court }\end{array}$ & $\begin{array}{l}\text { 2013: } 292 \\
\text { m (road) }\end{array}$ & $\begin{array}{l}\text { Local budget: } \\
188 \text { million } \\
\text { IDR }\end{array}$ & $\begin{array}{l}\text { The local } \\
\text { government }\end{array}$ \\
\hline
\end{tabular}

Source: Author's compilation based on Banjarmasin City

government's document (various years)

An interesting finding regarding the river normalization process in section 5 (referring to the Old Market Waterfront) was that the cleaning process and the construction part was financed by the local government budget. Section 5 was an advanced project from the Grand Mosque Waterfront section, which was built by the provincial government.

The cleaning process was quite difficult and it took several months. The execution that should have been completed by January 2011 was delayed until May 2011. There were some problems during the process, including the property price negotiation and the administration problems related to the evaluation by the provincial government (Narti, Kalimantan Post, 2011; Fathila, Banjarmasin Post, 2011).

The property price negotiation was the crucial problem at the time because some of the households wanted to get a higher price than the appraisal price
(NN, Banjarmasin Post, 2010). The appraisal team released a property price around of 900,000 IDR per $\mathrm{m}^{2}$ (approximately 68 USD per $\mathrm{m}^{2}$ ) and some of the households did not agree about the price and wanted to get compensation around of 5 million IDR per $\mathrm{m}^{2}$ (approximately 376,000 USD per $\mathrm{m}^{2}$ ) (NN, Banjarmasin Post, 2010; Fathila, Banjarmasin Post, 2011). The negotiation was quite difficult; even the local government sent warning letters twice.

Finally, in May 2011, the households and the appraisal team reached an agreement about the property price. The agreement included 37 households, consisting of 25 documented households and 12 undocumented households with a total length of around $200 \mathrm{~m}$ land acquired. The local government allocated around 1.8 billion IDR (approximately 135,000 USD), but around 69 million IDR was left unused (approximately 5,200 USD) (Narti, Kalimantan Post, 2011).

After the local government was finished with the cleaning process, the construction took almost four years. In the first years, the local government built a $101 \mathrm{~m}$ long riverwalk, with a total budget of 8.6 million IDR (approximately 646,000 USD). Later in 2014-2015, the local government decided to continue building the waterfront to $300 \mathrm{~m}$ length with total budget 20 billion IDR (approximately 1.5 million USD) (Department of Water Resource and Drainage, 2014).

Therefore, almost all the river normalization process in the Banjarmasin waterfront had the same problems in the cleaning up process, which involved property price negotiations. But, the negotiations in all the sectors reached an agreement in the end.

\subsection{Second Phase: Creating a New Economy}

After finishing the construction in the northern area, the local government tried to develop opportunities for promoting tourism. There were two main tourist attractions aimed to promote local tourism - the floating market activity and visiting the craft villages.

The floating market activity and its uniqueness is main tourist attractions that tend to promote local tourism in this area. Floating market activity is supported and accommodated by the local government by providing special subsidies, such as transportation and lunch. That activity takes place every weekend only, between Saturday noon and Sunday noon and is managed through the floating market association. The local government, through the Department of Tourism in 2014, created this association with 64 female members as retailers and 6 male members as coordinators as confirmed by the Head of the Tourism Development Division's statement, “...total of the retailers and the crews are 70 people, consist of 6 male coordinators and 64 acil (Khuzaimi, personal communication, June 14, 2016)".

However, the floating market in Piere Tendean Park is quite different as compared to the floating market in Kampung Kuin (see Table 5). All members of the floating market live in Banjar Regency, located outside Banjarmasin City. Because of their location, the local government provides special subsidies to them, such as transportation and lunch. According to the Head of the Tourism Development Division: 
"...we give transportation fee. And as long as the activity hold in there, 6 people as guard man for the sellers. They arrive on location hours $14.00 \mathrm{pm}$ or $14.30 \mathrm{pm}$ in the afternoon then they continue to trade their items. They start their trade from Saturday noon/evening until Sunday noon we drove them home. On Saturday night acil sleeping in lanting (Khuzaimi, personal communication, June 14, 2016)".

Another statement about the floating market system comes from the leader of floating market association:

"...my job here to pick the retailers to Floating Market Piere Tendean. Usually, we are going on Saturday noon from our home and going back on Sunday noon to our home. We stayed overnight here. All the transportation fee covered by the local government (Arul, personal communication, June $25,2016) "$

Table 5 summarizes the characteristics of the two floating market in Banjarmasin City, one in Piere Tendean Park and the other in Kampung Kuin.

Table 5. Characteristics of Floating Market in Banjarmasin City

\begin{tabular}{|c|c|}
\hline $\begin{array}{c}\text { Floating } \\
\text { Market }\end{array}$ & Characteristic \\
\hline $\begin{array}{l}\text { Floating } \\
\text { market in } \\
\text { Piere } \\
\text { Tendean }\end{array}$ & $\begin{array}{l}\text { - Located in Gadang kelurahan, Central } \\
\text { Banjarmasin sub-district (in Banjarmasin } \\
\text { downtown). } \\
\text { - Concept: Using (1) jukung as both store and }\end{array}$ \\
\hline
\end{tabular}

Park transportation mode, (2) lanting as display store, and (3) static activities trading.

- Only held on weekends and other special occasions.

- There is an association with 64 female members. Floating

- Origin of the retailers: The floating market Lok Market

Baintan in Banjar Regency or around $25 \mathrm{~km}$ from Banjarmasin downtown.

Floating - Located in Kuin Cerucuk and Kuin Utara market in kelurahan, North Banjarmasin sub-district.

Kampung - Concept: Using jukung as both store and

Kuin transportation mode, and mobile activities trading.

- Takes place as an everyday life activity, from early in the morning to around 9 am.

- Around 80 retailers, but no association (data from 2009).

- Around $5 \mathrm{~km}$ from Banjarmasin downtown.

- Origin of retailers: Local people from

Banjarmasin city, such as Kuin, Alalak Selatan,

Alalak Utara, Sungai Miai, Sungai Pangeran; and outside city, usually northern area of Banjarmasin such as Banjar, Barito Kuala, Tapin; and Hulu Sungai Selatan Regencies (data from 2009).

Source: Aut hor's compilation based on questionnaires (2017).

For data Kampung Kuin floating market using author's undergradua te paper (2009).
The existence of the floating market activity in Piere Tendean Park benefits both the public and private sectors. According to one of the owners of a travel agency in Banjarmasin:

"The existence of Piere Tendean Park is very good, the location in riverside of Martapura River more organized and cleaner than before. And Piere Tendean Park is very suitable for tourism while sightseeing of the river. The more important is free, Piere Tendean as a public space, with other supporting facilities. Besides that, Piere Tendean Park has floating market. And the floating market is image of Banjarmasin, because the other city does not have that (Sai, personal communication, June 29, 2016)".

To understand the economic activities of Piere Tendean floating market, this research distributed 37 questionnaires to the retailers (see Table 6). According to its results, the main occupation of the respondents was retailing (around 76\%), followed by farming (14\%), and only $10 \%$ were involved in both the occupations. An interesting find from the survey on the main occupation of the respondents was that besides being retailers in Piere Tendean floating market on weekends, they are also the retailers in Lok Baintan floating market, locat ed near their residential area, every weekday. Th e floating market retailers usually s ell fruits, vegeta les and local food to the customers. All the commodities in the market come from different sources, suchas the seller's own harvest or gods bought from others.

\section{Table 6. New Economy in the Waterfront}

\begin{tabular}{|c|c|}
\hline $\begin{array}{l}\text { Association's } \\
\text { Name }\end{array}$ & Characteristics \\
\hline $\begin{array}{l}\text { Floating } \\
\text { Market }\end{array}$ & $\begin{array}{l}\text { Held only on weekends, from } \\
\text { Saturday noon to Sunday noon, } \\
\text { except for special occasions, such as } \\
\text { Banjarmasin City anniversary and } \\
\text { floating market festival. } \\
\text { - A total of } 70 \text { members, consisting of } \\
64 \text { females as retailers and } 6 \text { males } \\
\text { as coordinator. } \\
\text { - Education: Elementary (24\%), senior } \\
\text { high school (30\%), junior high } \\
\text { school (41\%), and no answer (5\%). } \\
\text { - Main occupation: Retailer (76\%), } \\
\text { farmer (14\%), and both the } \\
\text { occupations (10\%). } \\
\text { - Commodities: Fruits ( } 35 \%), \\
\text { vegetables (32.5\%), and local food } \\
\text { (32.5\%). } \\
\text { - Origins from Banjar Regency } \\
\text { - The government provides subsidies } \\
\text { by giving them a transportation fee } \\
\text { through coordinators and free one- } \\
\text { time lunch. }\end{array}$ \\
\hline Boatmen & $\begin{array}{l}\text { Everyday activities. } \\
\text { - Total numbers of members are } 54 \\
\text { male boat riders. }\end{array}$ \\
\hline
\end{tabular}


- Education: Elementary (10\%) and junior high school (90\%).

- Main occupations: Boatman (93\%), and farmer $(7 \%)$

- Commodities: Services for river cruise, consisting of short and long routes.

- Origins: Local people from Banjarmasin City, such as Kuin Utara, Antasan Raden, Teluk Tiram, Benua Anyar, Kelayan, Sungai Jingah; and outside city, from Banjar and Barito Kuala Regency.

- The local government conducts inspections for boat conditions and issues eligibility letter for the boats. Some aids like life-jackets from a third party (an Indonesian bank)

Source: Author's compilation based on questionnaires (2017)

Respondents also stated that their total income increased after joining the Piere Tendean floating market association, because many visitors come to Piere Tendean waterfront either for enjoying the floating market or for just sightseeing, with the numbers varying from 27,000 to 46,000 visitors per week (Boatmen Association documents, 2017). Furthermore, there were significant differences (see Table 9) when comparing the incomes of the retailers who operate in the weekday floating market and the weekend floating market.

Table 7. Income of floating market retailers

\begin{tabular}{lcc}
$\begin{array}{l}\text { Range of income } \\
\text { per week }\end{array}$ & $\begin{array}{c}\text { Income per week } \\
\text { on weekdays } \\
\text { floating market }\end{array}$ & $\begin{array}{c}\text { Income per week } \\
\text { on weekend } \\
\text { floating market }\end{array}$ \\
\hline $\begin{array}{lcc}<100,000 \text { IDR } \\
(<7.5 \text { USD) }\end{array}$ & $35 \%$ & $5 \%$ \\
\cline { 1 - 1 } $\begin{array}{l}100,000-250,000 \\
\text { IDR (7.5-19 USD) }\end{array}$ & $41 \%$ & $39 \%$ \\
\cline { 1 - 1 } $\begin{array}{l}250,000-400,000 \\
\text { IDR (19-30 USD) }\end{array}$ & $21 \%$ & $35 \%$ \\
\cline { 1 - 1 }$>$ 400,000 IDR & $0 \%$ & $21 \%$ \\
(>30 USD) & & \\
\hline
\end{tabular}

Note. Weekdays floating market refers to Lok Baintan floating market located in Banjar Regency, and weekend floating market refers to Piere Tendean floating market in Piere Tendean Park.

Source: Author's compilation based on questionnaires (2017)

Respondents also showed their high expectation for the improvement of the floating market facilities, particularly during rainy season because, according to them, there are only a few customers coming to the market when the condition at the waterfront is wet, thus affecting their business.

The second association is the boatmen's association having 54 members. Boatman activities are quite different from floating market activity held every day.

According to the 30 respondents among the boatmen, $90 \%$ lived in the Banjarmasin area and only $10 \%$ lived outside Banjarmasin. Being a boatman was the main occupation of $93 \%$ of the respondents, while the others considered it as a secondary job. For people who were boatman as their main occupation, they almost definitely drive their boats every day, carrying more than 10 customers.

According to them, all their customers were local people who enjoy the river. Respondents also said that their total income earned as a boatman increased because of the same reason as the floating market members, which is the existence of floating market activities held every weekend and local people who want to enjoy the river. Therefore, all the respondents said that they get an additional income of around 100,000-250,000 IDR per week (approximately 7.5-19 USD per week).

Another interesting find about the boatmen's association was their method of deciding the boat ride prices. According to them, it was decided by a meeting with all the members. Furthermore, the prices for the two routes of the river cruise were decided, the short route from Piere Tendean floating market-Old Market bridge-Antarasi bridge-floating market was priced at 5,000 IDR person (approximately 0.4 USD per person) and the long route from Piere Tendean floating market to Kembang Island would cost 35,000 IDR per person (approximately 2.6 USD per person) for round trips.

The respondents also said that they were satisfied with this association because their incomes had increased and there was good management of customers, wherein all the members would get customers fairly.

\section{Visiting Craft Villages}

There are two main craft villages that play an important role to promote local tourism. Both of the craft villages are known for specialty products named after the community itself. First, on the North side of Piere Tendean Park (Section 2) there is Sasirangan village, located at Seberang Masjid Street (Seberang Masjid kelurahan). It is named after the main product of that area, Sasirangan. The term Sasirangan comes from the Banjar word sirang, meaning, "to stitch together", expressing the hand stitching and dying process of the traditional fabric. Sasirangan is similar to Javanese Batik, which is used as a traditional cloth. The Ministry of Tourism appointed Sasirangan village as one of the tourist destinations in 2010 (Ministry of Tourism, 2016). There are 73 craftsmen currently living in this village (Prasetiyo, Arisanty, \& Nugroho, 2014).

Second, on the South side of Bekantan Park, there is Ketupat village, located in Sungai Baru kelurahan across the Sungai Baru waterfront in Section 3. It is named after the main product of the village, Ketupat, which is the main ingredient of traditional Banjarese local food.

All the tourist attractions can be accessed only by land transport. Public transportation served only by taxis, take around 40 minutes from airport (a distance of around $25 \mathrm{~km}$ ). The local government supports all these tourist attractions because they want to promote such locally produced and unique products.

On this phase, the local government succeeded in promoting local tourism by increasing the number of visitors, about double compared with before and increasing income of key actors. 


\subsection{Third Phase: Rediscovering Identity}

Floating market activity is an important traditional river culture in Banjarmasin City. Revitalizing floating market activities in the Banjarmasin waterfront will strengthen Banjarmasin's image as the city of a thousand rivers.

Long before the floating market activity became the main attraction in the Banjarmasin waterfront, they were a part of the history of the Banjar Kingdom. The market was already operational around 1526, when the Banjar Kingdom was built (Adonis \& P. , 1991). Originally, its activities were located in Kampung Kuin, the central business sub-district of the Banjar Kingdom, where many merchants from other areas gathered (Adonis \& P., 1991; Seman, 2004). When the Dutch ruled the place, there were changes in the economy and trade activities because of the expansion of settlements. Many river settlements, such as Kampung Pacinan Laut, Kampung Antasan Besar, Kampung Teluk Dalam, Kampung Jawa, Kampung Banjar, and Kampung Keraton were built at the time, and it affected the floating market in Kampung Kuin, which was the central business center (Adonis \& P. , 1991).

Fluctuations in the role of the floating market also affected the Banjar Kingdom's relocation from Kampung Kuin to Pulau Tatas in response to the arrival of the British in 1701. Pulau Tatas later became the Banjarmasin downtown of today, where the Grand Mosque was built, located in Antasan Besar kelurahan, Central Banjarmasin sub-district. This was followed by the arrival of the Dutch when they made Banjarmasin the capital of "Gouvernement Borneo" in 1937 (Saleh, 1981). Banjarmasin City is still the capital of South Kalimantan Province.

Floating market activities as a tourism attraction in Kampung Kuin exists even today. But, according to Erizal (2003), using the ingredients of success model by Garvin (2002), the programme to revive the floating market in Kampung Kuin failed because the role of the provincial government was too large while that of the local government was too small. Besides the role of entrepreneurship had been ignored, leading to a failure in gaining investment to strengthen the floating market as a tourism attraction.

Besides the floating market activity, on the West side of Piere Tendean Park, there are two religious centers. The Grand Mosque Sabilal Muhtadin located in Sudirman Street. It is used as a religious and educational center for Muslims. It was built in 1981 on the ground of the former Tatas Army Dormitory Complex of Republic Indonesia, or what was called Fort van Tatas when the Dutch ruled the place (NN, Radar Banjar, 2016). The Protestant Church Maranatha Banjarmasin is also located in this region. After its renovation, it adopted a Banjarese roof architectural style. It is located near the Grand Mosque. Along Sudirman Street, there is car free day, every Sunday morning.

At Piere Tendean Street, there is the Piere Tendean Park. It became the center of tourist attractions in Banjarmasin. It has a $1 \mathrm{~km}$ long river walk. The park has 3 main segments with their own distinct characteristics. The North side of the park is called segment A. According to the blueprint, it should have an art gallery and mosque, as a point of interest. But then, the local government only implemented the river walk and retained the old mushalla, without replacing it with a mosque.

The second section is called segment B. It should have had an archaeological site, an ex B-park, and a main gallery. In segment B, the ex B-park has been implemented as a Green Park, and the main gallery consists of a viewing tower and the House of Anno; both buildings are managed by the Department of Tourism, Art, and Culture.

The viewing tower has four floors and each floor has its own functions. The first floor is usually used as open public space and as the control office of the Department of Tourism, Art, and Culture. The second floor is used as tourist information center and office, while the third floor consists of outlets of small and medium enterprises. The fourth floor is used as a viewing area for the public to enjoy the Martapura river view.

The House of Anno was built in 1925. It has a colonial architectural style with ironwood walls, but unfortunately it had been vacant for a long time. Previously, it was used as a church, which was later renovated into a warehouse. When it became an asset of the Banjarmasin government, they revitalized it as an open public space (Building Management and Environmental Plan, 2011). Since 2010, discussions between the Banjarmasin government, cultural experts, and the Archaeology Centre of South Kalimantan Province agreed upon the decision to make the House of Anno a traditional building (Department of Spatial Planning, Human Settlement, and Housing document, nd). After the rehabilitation, the House of Anno opened as a public art gallery on the first floor, and a café on the second floor (Khuzaimi, personal communication, June 14, 2016).

The last segment $\mathrm{C}$ is known as the floating market area. According to the blueprint, it should have been a public space area displaying Chinese Historical Art and Culture. But, the implementation of this plan is only seen in the public space area. Currently, the segment C is located in the Piere Tendean floating market and at the boat terminal for the river cruise.

Besides these activities, the Banjarmasin waterfront regularly holds floating market festivals. It presents Banjarese village, jukung ornamental race, cultural parade, culinary event, local traditional games, and many aspects of Banjarese culture is put on display. It is held every September, during the birth anniversary of Banjarmasin City.

Bekantan Park is located beside Piere Tendean Park. It has a $204 \mathrm{~m}$ long river walk. There is a Bekantan statue; statue is as high as $6.5 \mathrm{~m}$, and a basketball court, as a public open space. Bekantan (Nasalis larvatus), the Banjarmasin City mascot, is one of the monkey species, which has a unique figure, with a long nose and reddishbrown hair. The park is also named after it.

Across the Bekantan Park, there is a Confucius temple named Soetji Nurani. It was built in 1898 and its design has Feng Shui principles applied to it. It is one of the oldest and largest temples in Banjarmasin (Widiastuti \& Oktaviana, 2012).

\subsection{Discussion}


The urban waterfront redevelopment concept has been adopted in many countries. The common concept of urban waterfront redevelopment is the revive land. In the case of Banjarmasin, urban waterfront redevelopment has been the product of cleaning up the riverside area from housing settlements.

Findings suggested that the government, especially the local government, initiated all the waterfront projects. However, the work started after decentralization was implemented, because decentralization gave an opportunity for the local government to manage and promote their local identity.

From the findings mentioned above, there are three kinds of funding and constructing processes that were implemented in the area. First, the central government was responsible for both funding and constructing of waterfront projects. Second, there was transfer of money from the central government to the local government, which was responsible for constructing the waterfront projects. And third, all the budget and development process were the local government's responsibility. The central government supported the development of the waterfront projects by directly funding and constructing it or transferring funds through the local government. All the waterfront projects were started after decentralization.

It seems that decentralization become the key factor in the Banjarmasin waterfront projects. After the Asian Finance Crisis in Indonesia, followed by the fall of the Suharto Era, many regions in Indonesia asked for the distribution of power from the central government to the local government. This project was also replaced from the centralized system by the decentralized system.

After the implementation of decentralization in Indonesia, the local authority was given the responsibility to manage their own regions. The local authority was made completely responsible for, and in charge of, the economic development of its city, as compared to the Suharto Era, where every leader of the regions was appointed by the central government. South Kalimantan Province also experienced leadership by an outsider with a military background, not the local people. After President Suharto stepped down, South Kalimantan for the first time conducted direct elections for the first time as they choose their own leader. After the local leader stepped up for the elections, many of them tried to explore the local wisdom by giving the city its identity. It was different in Makassar case, which never experience leadership by an outsider, before or after the Suharto era.

Learning from the previous researches related to Kampung Kuin, there is an important role of the local government in the management of the local resources while retaining its specialty. Most studies have assumed that local authority has an important role in the urban waterfront redevelopment process, including the economic improvement of its city (see in Garvin, 2002; Erizal, 2003; Cadell, Falk, \& King, 2008).

The Banjarmasin waterfront seems to fulfill the combination of the three important things, as opined by Hoyle. First, with regards to the adaptation of the past and the present, the local government tried to revive the floating market, thus linking the traditional river culture to the other cultural aspects, especially the Grand Mosque at a heart of the city, which will strength Banjarmasin's image as "the city of thousand rivers". Second, Banjarmasin City seeks to leverage its uniqueness by attracting tourists and creating a new economy. And last, the Banjarmasin waterfront redevelopment process also involves the floating market, the boatmen's association, and the craft villages' participation to strengthen the local tourism.

Findings also suggested that the three phases of Banjarmasin waterfront redevelopment process were successful. In the first phase, the constructive part was the success in cleaning up the riverside area from the housing settlements. But, during the process, the local government only provided compensations for the exhouseholders for their land and house, without considering their well-being. The local government did not provide flats or subsidized houses for them.

The next phase, which involves creating a new economy, was also s success since the number of visitor doubled compared to the earlier days, and the income of the floating market retailers and river cruise boatmen also increased. The local government also ensured that the second phase was successful by giving special subsidies for developing the floating market activity as a main tourist attraction, such as transportation and lunch. Besides, for tourists' safety, the local government through the Department of Transportation, Communication, and Informatics, also arranged for the boatmen to get a license.

This situation was quite different for Singapore or Makassar. In the case of Singapore, it was more focused on physical development, which led to a loss of its local culture. The Makassar waterfront showed us the success of physical development and promoted local tourism only. Although, the Banjarmasin waterfront is just a new-comer among the many urban waterfront redevelopment projects, the local authority succeeded in attaining both physical development and maintaining the traditional river culture as a local identity along with the river.

Generally, academic research related to decentralization or local development after the Asian crisis shows the tendency of physical development such as economic development including public works, education, and health. Compare to these development, the Banjarmasin project shows another option for development, such as rediscovering identity through the redevelopment of a river as the basic environmental identity, by locals and not outsiders, not military and not under the control of the central government.

\section{Conclusion}

The objective of this study was to evaluate the Banjarmasin waterfront redevelopment processes, consisting of the three phases of river normalization process, creating a new economy, and rediscovering an identity. This study has found that Banjarmasin waterfront succeeds in both its physical development and creating a city identity. 
Another finding also suggested that decentralization has a huge part to play in the Banjarmasin waterfront process. After decentralization was implemented in Indonesia, the local government started to manage and promote its own region. In Banjarmasin's case, the Banjarmasin government gave more attention to the waterfront projects by allocating a huge budget as one of the four biggest allocations, after road, education, and health.

Furthermore, the author would like to suggest two points. First, the local government needs to make partnerships with the private sectors to support the Banjarmasin waterfront projects, because all phases are initiated and funded by the government, both local and central. The local government also needs to maintain the sustainability of the floating market by encouraging retailers to be more independent.

Second, the local government needs to give more attention to the cleaning up process. It needs to provide and support the ex-householders of the riverside area by providing flats or initiating subsidized houses programmes for them.

This study also has certain limitations because it has only evaluated half of the Banjarmasin waterfront projects, while the whole project consist of nine sections. Therefore, the analysis is not yet comprehensive. Further studies need to be conducted to provide data about the whole Banjarmasin waterfront redevelopment project.

This study also has certain limitations. First, on the river normalization process, the author only gathered data from the government documents about the compensation prices, and on the government view, the physical development of river walk succeeded. But, the other hand, the condition of former householders still yet get attentions from the local government, either their condition were improved or decreased after the cleaning up process by the local authority. For the further studies need to distribute questionnaires for former householders ask about their condition toward the Banjarmasin waterfront redevelopment projects.

Besides that, there is need to explore in-depth about role of the central on the Banjarmasin waterfront redevelopment projects. Because of some sections were funded by the central government.

\section{References}

Adonis, F. T., \& P, I. N. (1991). Peranan Pasar Apung Terhadap Masyarakat disekitarnya (The role of the floating market towards its neighbourhood) . (S. Galba, Ed.) Banjarmasin, South Kalimantan: Education and Culture Department.

Batas Waktu 21 December. (2011, December 17). Banjarmasin Post. Retrieved from https://issuu.com/deny bpost/docs/bp20111217
Breen, A., \& Rigby, D. (1994). Waterfronts Cities Reclaim Their Edge. New York: McGraw-Hill, Inc.

Brenn, A., \& Rigby, D. (1996). The New Waterfront: A Worldwide Urban Success Story. New York: McGraw-Hill, Inc.

Building Management and Environmental Plan (Rencana Tata Bangunan dan Lingkungan/RTBL) Veteran and Piere Tendean area in Banjarmasin. Banjarmasin. Not published.

Cadell, C., Falk, N., \& King, F. (2008). Regeneration in European cities: Making connection. Urban and Economic Development Group. Joseph Rowntree Foundation.

Chang, T. C., Huang, S., \& Savage, V. R. (2004). On the waterfront: Globalization and urbanization in Singapore. Urban Geography, 25 (5), 413-436.

Couch, C., Sykes, O., \& Borstinghaus, W. (2011). Thirty years of urban regeneration in Britain, Germany and France. Progress in Planning , 75, $1-52$.

Dong, L. (2004). Waterfront Development: A Case Study of Dalian. Thesis. Canada: University of Waterloo, Waterloo's Institutional Repository.

Erham, A., \& Hamzah, A. (2014). An Evolution of Urban Waterfront and Tourism. Asian Journal of Social Sciences \& Humanities , 3 (4), 124-131.

Erizal, U. (2003). Evaluasi Terhadap Revitalisasi Pada Kawasan Tepi Sungai Kuin di Banjarmasin (Evaluation of Revitalization at Kuin River Edge in Banjarmasin). Thesis. Yogyakarta: Gadjah Mada University.

Ganti Rugi Harus Sesuai. (2009, August 18). Banjarmasin Post. Retrieved from https://issuu.com/deny bpost/docs/bp20090818

Garvin, A. (2002). The American City What Works What Doesn't (Second ed.). New York: McGraw-Hill, Inc.

Goodwin, R. F. (1999). Redeveloping deteriorated urban waterfronts: The effectiveness of U.S. coastal management programs. Coastal Management , 27 (2-3), 239-269.

Gotham, K. F. (2001). Urban redevelopment, past and present. Critical Perspective on Urban Redevelopment , 6, 1-31.

Hou, Diyun. (2009). Urban Waterfront Landscape Planning. Thesis. Karlskrona: Blekinge Institute of Technology.

Hoyle, B. (2000). Global and local change on the portcity waterfront. Geographical Review , 90 (3), 395-417.

https://banjarmasinkota.bps.go.id/index.php

Kenanga Pun Ikut Tergusur. (2011, April 7). Banjarmasin Post. Retrieved from https://issuu.com/deny bpost/docs/bp20110407

Lagarense, B. E., \& Walansendow, A. (2015). Exploring residents' perception and participation on tourism 
and waterfront development: The case of Manado waterfront development in Indonesia. Asia Pacific Journal of Tourism Research , 20 (2), 223-237.

Local Regulation Banjarmasin Municipality No. 32/2014 About Local Budgeting Year 2015 and Regulation of Banjarmasin Major No. 108/2014 About Local Budgeting Year 2015. Retrieved from http://bpkad.banjarmasinkota.go.id/download/cat view/42-dasar-hukum-apbd-murni-dan-apbdperubahan-2015.

Mayor Decree No. 103 Year 2008 regarding the Amount of Building Compensation in Piere Tendean Street. Banjarmasin: Not published.

Ministry of Tourism, Republic of Indonesia. (2016). Sasirangan: Traditional South Kalimantan Fabric with Distinct Banjar Motif. Retrieved from http://www.indonesia.travel/en/destination/pointof-interest/sasirangan

Monthly Report from Department Water Resources and Drainage from 2009-2015. Banjarmasin. Not published.

Muhidin Incar PKL Tendean. (2010, August 16). Banjarmasin Post. Retrieved from https://issuu.com/deny bpost/docs/bp20100816

Pemilik Lahan Piere Tendean Setuju Dibangun Siring. (2009, August 12). Kalimantan Post. Retrieved from https://sijaka.wordpress.com/2009/08/12/23pemilik-lahan-piere-tendean-setuju-dibangunsiring/

Pemkot Segera Bebaskan Lahan Tendean (2012, July 27). Banjarmasin Post. Retrieved from http://kalsel.antaranews.com/berita/7664/pemkotsegera-bebaskan-lahan-tendean

Performance Report of Department Hygiene and Landscaping Banjarmasin Municipality Year 2015. Banjarmasin: Not published.

Performance Report of Department of Public Work Banjarmasin Municipality Year 2013 in attachment the Achievement of Performance Activities in 2013. Banjarmasin: Not published.

Prasetiyo, D., Arisanty, D., Nugroho, A. R. (2014). Upaya Pengrajin Sasirangan di Kampung Sasirangan Banjarmasin Dalam Menjaga Keberlangsungan Industri. Jurnal Pendidikan Geografi, 1 (2), 127-135.

Rifky, A. A., (2009). Fenomena Pasar Terapung Terhadap Kegiatan Sosial Ekonomi Masyarakat Muara Kuin (Floating Market Phenomenon Towards Social Economic Activities Muara Kuin Society). Undergraduate Paper. Yogyakarta: Gadjah Mada University. 